\title{
Pragmalinguistic Features of American Presidents' Inaugural Addresses of the Last Century (1913-2013)
}

\author{
Anna Gabets \\ Moscow State Institute of International Relations (MGIMO University) \\ Correspondence concerning this article should be addressed to Anna Gabets, MGIMO-University, 76 \\ Prospekt Vernadskogo, Moscow, Russian Federation, 119454. E-mail: annagabets@mail.ru
}

\author{
Arnau Barios Gené \\ University of Barcelona
}

\begin{abstract}
Correspondence concerning this article should be addressed to Arnau Barios Gené, Departament de Lingüística general, Filologia Eslava, University of Barcelona, Gran Via de les Corts Catalanes, 585, Barcelona.E-mail: arnau36@hotmail.com
\end{abstract}

\begin{abstract}
This paper studies the pragmalinguistic markers of the political discourse in American presidents' inaugural addresses made from 1913 to 2013 and concentrates on the language units that reveal the potential of perlocutionary speech acts. The study analyzes the role of such domains of pragmalinguistics as deixis, reference, presupposition, cognitive structures in inaugural addresses, and their representation in speeches. The method of discourse-analysis, the method of contextual analysis, and the method of quantitative processing are used in the study. The means of deixis have several functions in these speech texts, providing some extralinguistic information and additional meaning for the utterances. Firstly, the change of deictic center conveys a certain shift of attention and redirects the addressee's thoughts. Secondly, the means of deixis represent presuppositions, ones which members of the public are unlikely to question since these presuppositions are explicitly referred to and the information provided includes people's background assumptions. Thirdly, personal, temporal and spatial deixes are integrated in the actualization of the most important concept found in every speech of every American president - the concept of the "American nation": deictic forms along with nouns with evaluative implications add to the pragmatic effect of the concept reflected in speech. Fourthly, the deictic means participate in the construction of a binary that juxtaposes "us" vs. "them", typical of political utterances in the genre of inaugural addresses. A special form of reference constituting an important part of the concept of the "American nation" in inauguration addresses is precedent phenomena. Their main sources are the Bible, speeches of former politicians, texts of famous American documents. Reference to religious discourse and parts of national history familiar to everyone brings the feeling of joy to the public appealing to a basic national myth of a happy community. Thus means of deixis, presupposition and special type of reference are the characteristic of American inauguration speeches used for the purposes of strong pragmalinguistic effect. The dynamics of the usage of the precedent phenomena and other constituent parts of the concept "American nation" reflects the changes in political context of the epoch.
\end{abstract}

Keywords: political discourse, inauguration speech, pragmalinguistics, deixis, presupposition, reference, precedent phenomena, cognitive structures

Among all the speeches made on various occasions and ceremonial events by every president of the USA, inaugural addresses are probably the ones most remembered by future generations. Destined for millions of people in the home country and abroad, an inaugural address is carefully deliberated over and written in order to become an ideal sample of rhetoric, language and style. Aimed at defining presidential aims and goals for the duration of the new mandate, the President's utterance generally promises positive changes and future well-being and prosperity for the nation. Since George Washington's first inaugural 
address to the nation made on 30 April 1789, the specific genre of American inaugural speeches has been preserved and used for centuries. The ideas conveyed by the President through the selected language means have always been gladly and approvingly perceived by the public and have shaped the lives of American citizens for years.

Evidently, the word of a politician has a strong pragmatic effect and can change not only current political situations, which will definitely affect all the people, but also the ideas and the ideals of the masses, thus causing some social transformation since the values of social life are created, transferred and imposed on us by language. We all belong to different social institutions and for us utterances are actions. Discourse itself is a kind of linguistic action (Dijk, 2008, p. 203). On the other hand, the environment has a strong impact on political utterances. So the key role of language in our life is obvious, and the study of political discourse pragmatics concerning the context of the utterance is of vital importance.

The twentieth and the twenty-first centuries have been a time of great change in American and global history. Our research addresses how the transformations in global politics, economics and social structures during this period are reflected in the language of American presidents' inaugural addresses. Has the historical context somehow altered their form or their content? What are the similarities in the language used to produce the strongest effect on the listener? Are there any dynamics in the pragmatic discourse markers in inaugural speeches? A pragmalinguistic study of inaugural addresses can help to answer these research questions by examining the main linguistic mechanisms of political manipulation and explaining when and how language means depend on the fast-changing environment, even in such a relatively stable genre as inaugural speeches.

\section{Materials and Methods}

\section{Theoretical Background}

The language of politics is "the language of power, the power of persuasion and influence" (Bayram, 2010, p. 31). Political discourse is therefore usually specified in terms of such issues as manipulation, power and control. While an exact and unanimous definition of the kinds of utterances within political discourse remains problematic, formal speeches delivered by politicians during political ceremonies and within political institutions are perfect examples of this type of discourse. The linguistic means of manipulation and persuasion in the speeches can be identified and analyzed. Being a vital part of the culture and, in general, representing cognitive structures of the society, political leaders' speeches have aroused great scientific interest on the part of linguists. The instruments of content-analysis or cognitivediscourse analysis are frequently used in scientific studies (see Chudinov, 2006; Dijk, 2008; González Ruiz, 2008; Shapochkin, 2012). However, inaugural speeches by American presidents do not themselves often serve as the data for research, although they are examined with the same methods (Khromenkov, 2016). Instead, they are often studied from the perspective of applied linguistics and genre analysis (Campbell, Jamieson, 1986; Sheigal, 2002; Liu, 2012). The stylistic features of individual inaugural addresses have also been the focus of scientific study (see for example Anikina, 2015; De los Heros, 2003; al Shamari, 2015). However, to date, a complex study of the pragmatics of inauguration speeches has not been carried out.

Pragmatics is the study of speaker meaning, contextual meaning, of how more is communicated than is said, as well as the study of the expression of relative distance in speech (Yule, 2011, p. 3). The main fields of pragmatics can be effectively applied to the analysis of political utterances. The speech of a politician is formed under the influence of several factors: first, his or her language personality revealing different characteristics of an official position (gender, social, professional, age related status, cognitive base, worldview etc.); second, the communicative situation, that is, the political, economic, social, or historical context and the laws and algorithms of political discourse (Gabets, 2016, p. 108). These ideas correlate with the levels of political discourse described by van Dijk: the top level, which is constituted by socio-political, cultural and historical processes, political systems and their abstract representations; the intermediate level, which consists of political groups and institutions, their shared representations, relations and interactions, collective discourse; and the base level, which is represented by individual political actors, their beliefs, and discourses (Dijk, 2008, p. 204). Thus, speaker meaning and contextual meaning are interrelated and the units of the language used to form this meaning, add to the meaning, alter the meaning and express the relative distance are, in fact, quite numerous. Traditionally such language means are analyzed within domains of pragmatics such as deixis, background knowledge in the form of concepts, references, presuppositions, and so on.

One of the main fields in the sphere of pragmatics is deixis, the category that reflects the relationship between speech and its context, which is very important to the interpretation of an utterance. Personal deixis encodes the role of participants in speech. Temporal deixis is concerned with the various times involved in and referred to in an utterance. 
Spatial deixis indicates the distance of people and things in speech. As deictic means organize every conversation, different types of deixis are often found together within an utterance. Deictic markers usually reveal who is speaking, the time and the place of speaking, etc.; therefore, deictic expressions are most frequently egocentric (Vincente Mateu, 1994, p. 53) and linguists speak of the deictic center which represents the present time, location and role of the speaker (Cornish, 1996; Fillmore, 1975). Deixis is the means of constructing the opposition of "us" and "them" in the language. According to scholars, this opposition is considered to be archetypal, fundamental and traditional for every language (see Benveniste, 1966; Dijk, 1993). This discursive polarization is "typical for political discourse" and "not only reflects mental representations of people talked about, but also the categories of participants (represented in context models) talked to in a communicative situation" (Dijk, 2008, p. 226). The opposition implies the image of the enemy that was accentuated in inaugural addresses by P. N. Khromenkov who conducted a study of verbal expressions of conflict in the inaugural speeches of the presidents from the end of the eighteenth to the beginning of twentieth century. He came to the conclusion that the number of lexical units containing the meaning of 'enemy' or 'threat' was present in all the speeches examined, a number which was consistently growing in the 20th century (Khromenkov, 2016). Thus deixis together with other lexical units form a very influential part of any utterance.

One more domain of pragmatics is background knowledge. Background knowledge structures function like familiar patterns and are known as concepts: either semantic formation with linguo-cultural specificity (Vorkachev, 2004, pp. 38-39) or subjective elements of culture manifested in the language (Slishkin, 2004, p. 29). The interpretation of concepts as 'fragments of discourse' also belongs to the sphere of pragmatics because they define our ability to "arrive to interpretations of the unwritten and the unsaid" (Yule, 2011, p. 85). Some concepts express the key values of the culture and so are culture-bound. Based on his study of American culture reflected in the language, V. I. Karasik calls these concepts "regulative"; as an example, he offers the word "challenge", which is often used in political rhetoric as it implies success and the element of solemnity thus characterizing some special moments in life (Karasik, 2005, pp. 103-108).

Reference - an important field of pragmatics - is "an act in which a speaker, or writer, uses linguistic forms to enable a listener, or reader, to identify something" (Yule, 2011, p. 17). Along with nouns and pronouns, precedent phenomena can represent the category of reference since the physical environment has the most powerful impact on the way referring expressions are interpreted. Russian scholar Y. N. Karaulov was the first to introduce the idea of the "precedent text" and the term denoted a special text that is meaningful for an individual and, therefore, is often referred to and is known to a wide range of people (Karaulov, 1987, p. 216). Later, the term "precedent text" was changed to "precedent phenomenon" and further specified. Four types of precedent phenomena were identified: precedent name, precedent text, precedent utterance and precedent event (Krasnyh, 2002, pp. 47-49; Gudkov, 2003, pp. 104-107). All precedent phenomena function as elements of the discourse and, consequently, understanding them is vital to understanding the discourse itself. These are not precedent phenomena that are part of the cognitive base, but the invariants of their perception, which are each different and depend on the culture of the society in which they arise. Therefore, in terms of pragmatics, precedent texts, utterances, names and situations also belong to the sphere of background knowledge. As understanding of precedent phenomena can be different in various countries they were further divided into universally-precedent, nationally-precedent and socially-precedent categories (Krasnyh, 2002, p. 50).

Presupposition - another field in the domain of pragmatics - is voiced through personal, temporal and spatial deictic expressions and verbal actualization of precedent phenomena and cognitive structures in the speeches. Presupposition assumes some information is generally common knowledge and, therefore, "such information will generally not be stated and consequently will count as part of what is communicated but not said" (Yule, 2011, p. 25). According to Jones and Peccei, the technique of using presuppositions - background assumptions which are taken for granted to be true - is particularly useful in political discourse as it makes it difficult for the audience to identify or reject views that are communicated in such a way (Jones and Peccei, 2004, p. 44).

The domains of pragmatics mentioned above participate in the construction of positive selfrepresentation or argumentative speech strategies (Bassols, 2003). When combined, they transfer the meaning of the speech since this is always more than what is verbally expressed.

\section{Study}

The paper analyses such domains of pragmatics as deixis, background knowledge, reference and presupposition in 26 inaugural addresses made by 16 presidents of the USA from Woodrow Wilson to Barack Obama. The hypothesis of the study is that similar linguistic instruments of pragmatics can be found in all the speeches and that similar language means serve as pragmalinguistic markers of the political discourse in the speeches made from 1913 to 2013. The objectives 
of the paper are to identify these means and to study their evolution and possible dynamics.

The study is carried out with pragmaticcommunicative approach within the framework of a modern anthropocentric paradigm. A complex of methods is used for the purposes of the research: namely, the method of discourse-analysis and that of contextual analysis. The language units of are then examined through quantitative processing.

\section{Results}

Following our analysis of the category of deixis in 26 inaugural addresses, it has become apparent that personal, temporal and spatial deixes produce some extra-linguistic information and additional meaning of the utterance. Deictic center is often found in inaugural speeches for the purpose of positive selfpresentation, especially if it is the second presidential mandate and a report of the tasks fulfilled in the first mandate is expected. For example, from Woodrow Wilson's 1917 address:

The four years which have elapsed since last I stood in this place have been crowded with counsel and action of the most vital interest and consequence. Perhaps no equal period in our history has been so fruitful of important reforms in our economic and industrial life... It speaks for itself and will be of increasing influence as the years go by. This is not the time for retrospect. It is time rather to speak our thoughts and purposes concerning the present and the immediate future. (Wilson, 1917)

However, the deictic center can also be shifted to other participants and different times for pragmalinguistic effect, which is exactly what happens in all the inaugural addresses under examination: the means of deixis redirect the addressee's attention. In such cases the pronoun "I" is used less often than "we" in order to fill the audience with pride for what has been accomplished and cause them to identify with a feeling of national unity. The phrase clearly still implies a positive self-presentation strategy as the president verbally associates himself with the nation:. "We have built up, moreover, a great system of government [...] We have been proud of our industrial achievements [...] With this vision we approach new affairs" (Wilson, 1913). This pragmalinguistic tool is obviously not unique and is used in other languages as well; see, for example, the speech of Argentinean president Eva (De los Heros, 2003).

However, more often the presidents' inspiring words transmit the idea that the whole society should work together for its progress and prosperity. Linguistically, this concept requires a shift of responsibility, transferred through deictic expressions, and a shift of the deictic center as well. This is illustrated in Nixon's 1973 address: "In our own lives, let each of us ask--not just what will government do for me, but what can I do for myself?" (Nixon, 1973) as well as in Reagan's 1981 speech:

You meet heroes across a counter--and they are on both sides of that counter.... I have used the words "they" and "their" in speaking of these heroes. I could say "you" and "your" because I am addressing the heroes of whom I speak--you, the citizens of this blessed land. Your dreams, your hopes, your goals are going to be the dreams, the hopes, and the goals of this administration, so help me God. (Reagan, 1981)

It is clear from these examples that deictic expressions also assume that the addressees of the utterances are aware of their roles as participants in the context since they are explicitly referred to ("each of us", "you, the citizens" etc.).

Apart from the deictic expressions, the argumentative and positive self-presentation speech strategies are formed through nouns with evaluative implications which convey a positive attitude: "blessed land", "heroes", "dreams" and the feeling of pride is imparted to the recipients of the speech through the idea of the importance of every citizen also transferred by the means of deixis: "what can I do", "your dreams ... are going to be the dreams... of this administration".

The very genre of inaugural address presupposes the importance of the current moment; however, the elected presidents usually make references to the past and to the future as well. The past events mentioned belong to the domain of presupposition; the present ones to the deictic center; whereas the promises of future prosperity, typical of inaugural speeches and usually expressed through commissive speech acts, represent a solidarity strategy and also add to the pragmalinguistic effect of the utterance. This temporal frame is illustrated in the following extract from Reagan's 1981 address:

On the eve of our struggle for independence a man who might have been one of the greatest among the Founding Fathers..., said to his fellow Americans... Well, I believe we, the Americans of today, are ready to act worthy of ourselves, ready to do what must be done to ensure happiness and liberty for ourselves, our children and our children's children.... we will be seen as having greater strength throughout the world. We will again be the exemplar of freedom and a beacon 
of hope for those who do not now have

freedom. (Reagan, 1981)

Overall, the study shows that the role of deictic means is crucial in the construction of traditional political discourse, in general, and specifically in the juxtaposition of us/them in inaugural addresses. The image of the enemy - which was quite vague until 1949 became clear following Harry S. Truman's speech, then suddenly almost disappeared in 1997, but became subsequently present again after 2001 - was either verbalized by means of personal deixis "they" or "those who", by nouns such as "communism" and "imperialism", or by the proper name of the country, "Soviet Union". In the traditional archetypal opposition us/them, American presidents claim their country is always ready to help the poor and the miserable. Until 1949 , the attention was generally focused on their own homeland; post-1949, the attention shifted to all the people abroad. This is illustrated in Nixon's 1973 speech: "At every turn, we have been beset by those who find everything wrong with America and little that is right. But I am confident that this will not be the judgment of history on these remarkable times in which we are privileged to live" (Nixon, 1973). In this example, the pronoun "we" is again used for strategic purposes: the speaker represents himself as a group member excluding others from the group. The appellation to the group is not, however, objective but is a part of a traditional model of political discourse deploying an us/them opposition wherein the American nation is described as great and the concept of the enemy is alluded to. This oppositional structure is typical for the genre and is systematically verbalized: the us/them opposition has a strong pragmatic effect on the recipients as it gives the audience orientation marks, fostering the feeling of unity and integration to those who identify with 'us'.

\section{Background Knowledge - Concept "American Nation"}

The categories of time and space often expressed in inaugural addresses through temporal and spatial deictic means appeal to the cognitive and knowledge structures of recipients. So temporal and spatial deixis are also integrated in actualization of the most important concept found in every speech of every American president - the concept "American nation". The categories of time and space represented by deictic markers and expressions and tense forms of the verbs help to construct the image of this concept in political speeches. The American nation is shown as 'great' and 'exceptional' across time (past, present, future), in other words, forever. An example of verbalization of time and space categories introduced to the text for pragmatic purposes can be found in Harding's 1921 address: "Today, better than ever before, we know the aspirations of humankind, and share them. We have come to a new realization of our place in the world and a new appraisal of our Nation by the world... There was no American failure to resist the attempted reversion of civilization; there will be no failure today or tomorrow" (Harding, 1921). A similar concept of nationhood still resonates 80 years later: "Through much of the last century, America's faith in freedom and democracy was a rock in a raging sea. Now it is a seed upon the wind, taking root in many nations... and even after nearly 225 years, we have a long way yet to travel” (Bush, 2001).

The concept "American nation" is very complicated, broad and includes a big number of interrelated concepts, cognitive structures and scenarios. Therefore there are many language units verbalizing the mental formation (i.e.concept) in political speeches apart from deictic means. The results of the study showed that there are certain words and word combinations that express key concepts synonymous for the American lifestyle and can be found in every presidential speech and appeal to national cognitive structures: "hope", "faith", "peace”, "justice”, "equality", "opportunity", " rights", "beliefs", "loyalty", "change”, "dream", "dignity", "challenge", "renewal”, "democracy", "union", "responsibility", and "honesty". These lexical units have a positive meaning within American society. A quantitative study was conducted in order to identify the most important nouns and key values of American culture represented in inaugural addresses. The results show that "peace" and "freedom" are the most important interrelated concepts with that of "American nation". In order to compare these two with other important nouns, we provide data below for the first 10 most frequent nouns representing key values of American society:

Table 1

Quantity in inaugural speeches

\begin{tabular}{llc}
\hline \multicolumn{1}{c}{ Noun } & $\begin{array}{c}\text { Quantity in inaugural speeches } \\
\text { over 100 years (1913-2013) }\end{array}$ \\
\hline 1. & Peace & 163 \\
\hline 2. & Freedom & 151 \\
\hline 3. & Justice & 80 \\
\hline 4. & Change(s) & 76 \\
\hline 5. & Faith & 72 \\
\hline 6. & Responsibility/ies & 59 \\
\hline 7. & Democracy & 55 \\
\hline 8. & Hope & 52 \\
\hline 9. & Opportunity/ies & 52 \\
\hline 10. & Challenge(s) & 49 \\
\hline
\end{tabular}

According to the text of the speeches, the American nation was formed in freedom and has been, is and will be peaceful and prosperous for centuries because of its greatness. This message is echoed in President Obama's 2009 address: 
America will remain the anchor of strong alliances in every corner of the globe; and we will renew those institutions that extend our capacity to manage crisis abroad, for no one has a greater stake in a peaceful world than its most powerful nation. We will support democracy from Asia to Africa; from the Americas to the Middle East, because our interests and our conscience compel us to act on behalf of those who long for freedom. (Obama, 2009).

On the other hand, words that imply negative meanings, such as "dominion", "poverty", "suffering", "disease", "war", "tyranny", and "grief", become the contextual antonyms of the main concept in the speeches and are also frequent in the discourse. The concept "American nation" is always present in one of the first parts of the speech, which implies that it is being addressed to every person as a part of the nation; this provides people a feeling of importance, participation and unity. Deictic forms along with nouns with evaluative implications add to the pragmatic effect of the actualization of the concept in speech.

\section{Precedent Phenomena as a Special Means of Reference}

It is only natural that politicians use some elements of national context that can be shared by the whole audience, therefore, precedent phenomena are often found in the texts of the speeches. The most frequent type of precedent phenomena in inaugural addresses is precedent utterance, and the main source of the utterances is the Bible. Religion has always played a significant role in American public life and only a small percentage of Americans, according to a Gallup poll, say that they would "back a nonbeliever" (UsaToday. com, 2012). The idea of a nation chosen and blessed by God is at the heart of the concept of the 'American nation'. Thus prayers, words from the Bible, and the phrases "God Bless America!" or "God bless you" are mandatory for any inaugural address. The Holy Bible still remains an inseparable part of taking an oath and is, therefore, often mentioned in the speeches often supported by a quote from the precedent text. "Here before me is the Bible used in the inauguration of our first President, in 1789, and I have just taken the oath of office on the Bible my mother gave me a few years ago, opened to a timeless admonition from the ancient prophet Micah: "He hath showed thee, $\mathrm{O}$ man, what is good; and what doth the Lord require of thee, but to do justly, and to love mercy, and to walk humbly with thy God" (Carter, 1977).

It is an interesting fact that such a precedent text as the Koran was first invoked in a speech by George Bush in 2005, along with the famous Christian text of the 'Sermon on the Mount'. This precedent phenomenon reflects an important pragmalinguistic effect; it represents a change in American society wherein expressing the idea of freedom of faith (whatever the faith may be) to the whole world is a way of winning more supporters. That edifice of character is built in families, supported by communities with standards, and sustained in our national life by the truths of Sinai, the Sermon on the Mount, the words of the Koran, and the varied faiths of our people (Bush, 2005). Thus the appeal to the precedent text in the inaugural address serves as a tool of political technology.

The speeches of former presidents and politicians, stories of the Founding Fathers, and texts of the most famous American documents such as the American Constitution and the Declaration of Independence, are the second most frequent source of precedent phenomena. They are introduced in the text to convey the idea of American exceptionalism, distinguishing the U.S. from other countries, especially in terms of its history of formation. These texts reflect foundational ideas of the nation and their mental representation also belongs to the core concept "American nation". Therefore the name of George Washington - the Father of the nation - is widely used in the speeches as in the futher example.

"I have just repeated word for word the oath taken by George Washington 200 years ago, and the Bible on which I placed my hand is the Bible on which he placed his. It is right that the memory of Washington be with us today, not only because this is our Bicentennial Inauguration, but because Washington remains the Father of our Country" (Bush, 1989). Reference to religious discourse and parts of national history familiar to everyone brings the feeling of joy to the public by appealing to a basic national myth of a happy community of all the citizens of the nation.

Sometimes a precedent name or precedent text can belong to the sphere of literature and, if it is suitable for the moment and refers to some up-to-date events, can be used as part of a positive self-presentation strategy. Thus Richard Nixon quotes a contemporary poet referring to such an important achievement of the American nation as landing on the moon. The lines of the poet characterize the president as a wellread and intelligent person, remind the nation of its greatness and appeal to the national myth of unity and brotherhood. "In that moment, their view from the moon moved poet Archibald MacLeish to write: "To see the earth as it truly is, small and blue and beautiful in that eternal silence where it floats, is to see ourselves as riders on the earth together, brothers on that bright loveliness in the eternal cold - brothers who know now they are truly brothers" (Nixon, 1969).

If the Bible can be called a universally-precedent 
text, and events, speeches, texts and documents vital for the American history called nationally-precedent phenomena, then several usages of socially-precedent utterances can be noted. Foremost among these are the quotes of the presidents' former teachers, as noted in this extract from Carter's 1977 address: "As my high school teacher, Miss Julia Coleman, used to say: "We must adjust to changing times and still hold to unchanging principles'"(Carter, 1977). Notwithstanding the fact that the public is not familiar with the original utterances, such quotations also produce a strong pragmatic effect by characterizing the presidents as well-educated, respectful, thoughtful, and thankful members of the society who share something in common with the majority of the listening public. Again it conveys the idea of the greatness of the nation, one in which pupils are taught to be kind and decent people and good members of the society by their inspiring teachers.

The dynamics of the usage of the precedent phenomena in American inaugural speeches during the past 100 years is quite interesting and brings us back to the traditional us/them opposition in political discourse opposition. There are almost no precedent phenomena until 1941, but later politicians tend to refer to the names of the greatest members of the American nation, recall important events from American history and quote famous American ciitizens in their inaugural addresses.

If we compare these results with the findings obtained regarding the shift of political attention to foreign policy in 1949 and to more definite images of the enemy which also started to appear in speeches in 1949 , we can come to the conclusion that the whole life of the country was changing in the middle of the twentieth century; consequently, a stronger appeal to the idea of a unified nation and to American ideals through precedent utterances, either from the Bible or former American presidential speeches, was needed at that time to justify the right to fight some enemy on foreign grounds. The results of our research show that the concept of 'the enemy' in the twentieth century, particularly starting from the middle of the century, starts to become vivid. Whenever the image of the enemy of the nation is brightly described in the speech a national or universal precedent phenomena is almost sure to be found in the speech too in order to juxtapose the greatness of the nation to the weak points of its enemy. . The idea of American exceptionalism which began to thrive at this time, and the role of the USA as a world leader exporting peace and freedom abroad is evidenced through pragmalinguistic means as well. The dynamic of lexical representation of the central concept "American nation", including the idea of the enemy, is rich and belongs to the sphere of historic, political and economic context of the epoch.

\section{Presupposition}

The means of deixis included into the speech presupposes that listeners are aware of the context of the utterance: the time and the place of speaking, the history of the country: "America", "home", "abroad", "here", "four years ago", and "today". The president identifies himself with the nation strategically using the pronoun "we" instead of "I", thereby the addressee receives the message of the new coming era of happiness. The ideas can be illustrated by an abstract of Richard Nixon's speech. "When we met here four years ago, America was bleak in spirit, depressed by the prospect of seemingly endless war abroad and of destructive conflict at home. As we meet here today, we stand on the threshold of a new era of peace in the world" (Nixon, 1973). The president underlines that under his rule the country has achieved success in its goals but this is done implicitly as he identifies himself with the nation and through deictic means makes every member of the society responsible for the achievements thus giving the audience the feeling of joy and pride.

Precedent phenomena used in the texts of the speeches can also be regarded as the means of presupposition. Basically, they are introduced to the text in order to reveal the idea of unity and the greatness of the nation and of every member of the nation.

The choice of precedent phenomena is not random, every language unit applies to the public's cognitive base, ideals, background knowledge of national religion or history. The message that the nation is great is transferred through different means and some of these means may not be evident since they rely on presupposition. The means of presupposition also double the idea conveyed explicitly through the words. Thus in the following example the nation is explicitly called great and the precedent utterance that comes from the Bible once again reminds that the nation was chosen by God and is based on equality i.e. it squares with the national idea of great country again. "For myself, I ask only, in the words of an ancient leader: "Give me now wisdom and knowledge, that I may go out and come in before this people: for who can judge this thy people, that is so great?"” (Johnson, 1965). The second example manifests the shift of responsibility from the government to the public at the time of speaking (means of deixis are also implied) though concealed in the words of one of the founders of the nation.: "On the eve of our struggle for independence a man who might have been one of the greatest among the Founding Fathers, Dr. Joseph Warren, President of the Massachusetts Congress, said to his fellow Americans, "Our country is in danger, but not to be despaired of [...]. On you depend the fortunes of America. You are to 
decide the important questions upon which rests the happiness and the liberty of millions yet unborn. Act worthy of yourselves"” (Reagan, 1981). So he words of the president do not only remind the audience about the responsibilities but backs up the idea with reference to Founding Fathers - an integral part of the American culture, an appeal to which is supposed to impose the idea of unity. .

As nationally-precedent and universally-precedent phenomena like the Bible are parts of the cognitive base of society, they are also included in the concept "American nation" proving the exceptionalism and greatness of the society.

\section{Discussion}

The study illustrates that all domains of pragmatics analyzed in inaugural speeches work for the same purpose of influencing the audience, hence they are tools of implicit and explicit linguistic manipulation. The language means studied in the article cannot be mechanisms of only one field of pragmatics as demonstrated in the examples of deictic means or precedent phenomena. Depending on its function, a speech unit can be an instrument of reference, background knowledge, deixis, presupposition, or other fields of the science. Separating the domains of pragmatics in the research is done only conventionally as they are all combined in speech to produce the necessary effect of communicating more than what has actually been said. All the spheres are closely connected and interrelated; their coherence in speech is schematically presented in Figure 1.

The use of personal, temporal and spatial deictic means that are at the same time representing means of presupposition, appeals to cognitive structures through the actualization of precedent phenomena. Additionally, introducing nouns with evaluative implications into the speeches help to conjure up the most positive mental pictures of American history and well-being. The verbal representation of the concept of "American nation" is one of the most powerful pragmatic tools implied in the speeches since all the domains of pragmatics analyzed in the study help to construct it. In turn, the concept represents presupposition as it becomes next to impossible to disagree with the party line of the government, thus associating oneself with the great men of the past, present and the future: that is how this strategy typical of political discourse works. The noted dynamics and changes concerning the use of precedent phenomena and the sources of such language units and verbal representation of the image of the enemy also occurs for the pragmatic means. As the times are changing,

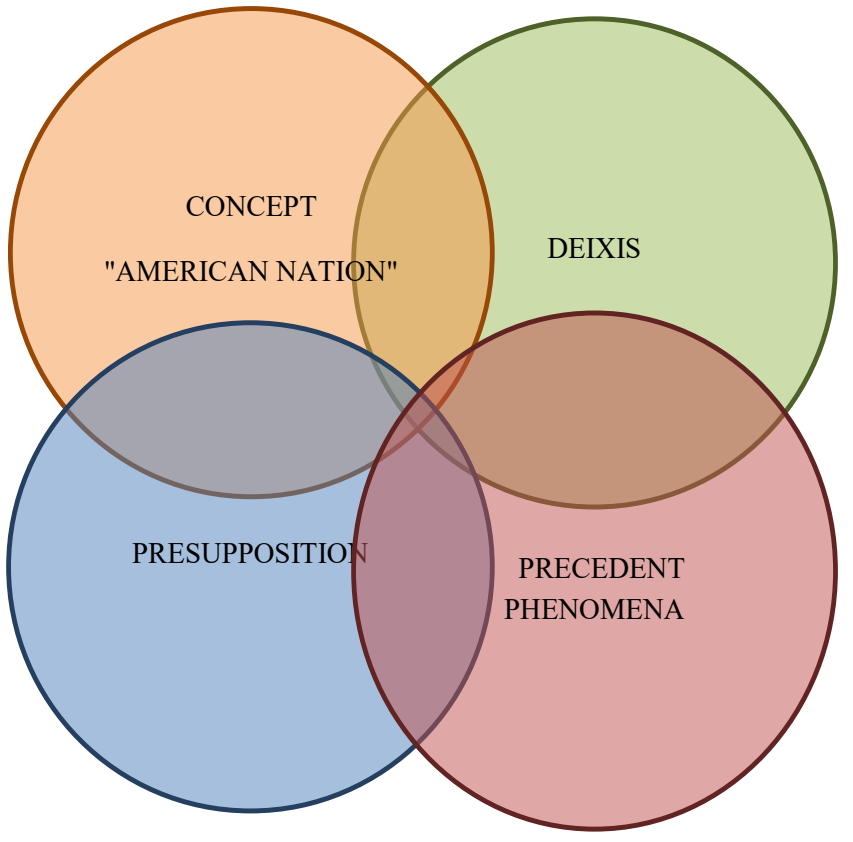

Figure 1. Coherence in speech.

American home and foreign policy is changing too and it is only natural that the context influences the correlation of linguistic means.

\section{Conclusion}

After having analyzed, from the perspective of pragmalinguistics, 26 inaugural addresses delivered by 16 presidents of the USA over the course of one hundred years, we confirmed our hypothesis that inaugural speeches are created using similar linguistic instruments. Language means representing deixis, presupposition, reference and background knowledge in the speeches all produce the same pragmatic effect: first, they foster integration into American society by instilling in each member of the public the feeling of individual importance and participation; second, they inspire joy and hope by appealing to a basic national myth of a happy American society and to the idea of American exceptionalism or greatness. They also function further as instruments for creating solidarity for the President through a positive self-presentation whether the President in question is new to the post or not. The evolution in the use of the language means representing the domain of pragmatics can be traced through the texts of the speeches from 1913 to 2013. Precedent phenomena and their sources, as well as the traditional us/them opposition in political discourse are the starkest examples of speech interacting with its context. The total number of the precedent phenomena is seen to grow when the attention of 
American authorities turns to fighting enemies abroad, as evidenced in the mid-century examples cited. In conclusion, the various pragmalinguistic markers studied within inaugural addresses of political discourse are responsible for constructing the correct and necessary meaning of the speech in the consciousness of recipients and, as such, are means of linguistic influence and manipulation.

\section{References}

Akinina,P.S.(2015).Stilisticheskie osobennosti,taktiki, funkcii i tematiko-ideologicheskie tendencii vtoroj inauguracionnoj rechi dejstvujushhego prezidenta SShA Baraka Obamy [The stylistic peculiarities, tactics, functions and thematic-ideological tendencies of the second inaugural speech of the current president of the USA Barack Obama]. Filologicheskie Nauki. Voprosy Teorii i Praktiki, 12(2), 16-19.

Aamal, A., \& al Shamari, H. (2015). Stylistic analysis of the two American Presidents' inaugural speeches: George W. Bush and Barack Obama. Retrieved from http://repository.uobaghdad.edu.iq/ArticleShow. aspx?ID $=5405$

Bassols, M. (2003, July 1). Pragmàtica i anàlisi del discurs. Noves SL [Pragmatics and discourse analysis. New SL]. Revista de sociolingüística. Retrieved from http://www.gencat.cat/llengua/ noves/noves/hm03hivern/docs/bassols.pdf

Bayram, F. (2010). Ideology and political discourse: A critical discourse analysis of Erdogan's political speech. ARECLS, 7, 23-40.

Benveniste, É. (1966). Problèmes de linguistique générale [Problems of general linguistics]. Paris, France: Gallimard.

Bush, G. H. W. (1989). Inaugural address. Retrieved from http://www.speaking-tips.com/Inaugural/ Bush-Inaugural-1989.aspx

Bush, G. W. (2001). Inaugural address. Retrieved from http://www.speaking-tips.com/Inaugural/BushInaugural-2001.aspx

Bush, G. W. (2005). Inaugural address. Retrieved from http://www.re-quest.net/history/inaugurals/bush/ gwb-second.htm

Campbell, K. K., \& Jamieson, K. H. (1986). Inaugurating the Presidency. In Form, Genre and the Study of Political Discourse (pp. 27-380). Columbia, SC: University of South Carolina Press.

Carter, J. (1977). Inaugural address. Retrieved from http://www.speaking-tips.com/Inaugural/CarterInaugural-1977.aspx

Chudinov, A. P. (2006). Politicheskaja lingvistika [Political linguistics]. Moscow, Russia: Flinta,
Nauka.

Cornish, F. (1996). 'Antecedentless' anaphors: Deixis, anaphora, or what? Some evidence from English and French. Journal of Linguistics, 32(1), 19-41.

De los Heros, S. (2003). Metáfora, referencialidad pronominal y uso de las descripciones definidas en el discurso político de Eva Perón [Metaphor, referentiality pronominal and use of the descriptions defined in the political discourse of Eva Perón]. In Pragmalingüística, 10-11, 95-110. Retrieved from http://revistas.uca.es/index.php/ pragma/article/viewFile/139/150

Dijk, T. A. (1993). Elite discourse and racism. Newbury Park, CA: Sage Inc.

Dijk, T. A. (2008). Discourse and power. New York, NY: Palgrave Macmillan.

Fillmore, Ch. J. (1975). Santa Cruz lectures on deixis: 1971. Bloomington, IN: Indiana University Linguistics Club.

Gabets, A. A. (2016). Actualization of gender roles in American politicians' election speeches. In Akademicheskaja nauka - Problemy $i$ dostizhenija (pp. 108-113). North Charleston, SC: USA RSS.

González Ruiz, R. (2008). Una cala en el lenguaje político español: Análisis lingüístico de un discurso parlamentario [A cove in the political language of Spanish: Linguistic analysis of a parliamentary speech]. In CAUCE, Revista Internacional de Filología y su Didáctica, 31. Retrieved from http:// cvc.cervantes.es/literatura/cauce/pdf/cauce31/ cauce_31_010.pdf

Gudkov, D. B. (2003). Teorija i praktika mezhkul'turnoj kommunikacii [The theory and practice of intercultural communication]. Moscow, Russia: Gnozis.

Harding, W. G. (1921). Inaugural address. Retrieved from http://www.speaking-tips.com/Inaugural/ Harding-Inaugural-1921.aspx

Johnson, L. B. (1965). Inaugural address. Retrieved from http://www.speaking-tips.com/Inaugural/ Johnson-Inaugural-1965.aspx

Jones, J., \& Peccei, J. S. (2004). Language and politics. In Thomas, L. (Ed.), Language, society, and power (pp. 46-68). New York, NY: Routledge.

Karasik, V. I. (2005). Koncepty-reguljativy [Regulative concepts]. In Jazyk, soznanie, kommunikacija (pp. 95-108). Moscow, Russia: MAKS Press.

Karaulov, U.N. (1987). Russkij jazyk i jazykovaja lichnost [Russian language and language personality]. Moscow, USSR: Nauka.

Khromenkov, P. N. (2016). Kontent-analiz inauguracionnyh rechej (na materiale rechej Prezidentov SShA konca XVIII-nachala XX vv.) [Content-analysis of the inauguration speeches (by the example of inaugural speeches of the USA Presidents from the end of XVIII till the 
beginning of XX century)]. Vestnik Moskovskogo Gosudarstvennogo Oblastnogo Universiteta, 1. Retrieved from www.evestnik-mgou.ru

Krasnyh, V. V. (2002). Jetnopsiholingvistika $i$ lingvokulturologija [Ethnopsycholinguistics and cultural linguistics]. Moscow, Russia: Gnozis.

Liu, F. (2012). Genre analysis of American Presidential inaugural speech. Theory and Practice in Language Studies, 2(11), 2407-2411.

Nixon, R. (1969). Inaugural address. Retrieved from http://www.speaking-tips.com/Inaugural/NixonInaugural-1969.aspx

Nixon, R. (1973). Inaugural address. Retrieved from http://www.speaking-tips.com/Inaugural/NixonInaugural-1973.aspx

Obama, B. (2009). Inaugural address. Retrieved from https://www.whitehouse.gov/blog/2009/01/21/ president-barack-obamas-inaugural-address

Reagan, R. (1981). Inaugural address. Retrieved from http://www.speaking-tips.com/Inaugural/ReaganInaugural-1981.aspx

Shapochkin, D. V. (2012). Politicheskij diskurs: Kognitivnyj aspekt [Political discourse: Cognitive aspect]. Tyumen, Russia: Izdatelstvo Tjumenskogo gosudarstvennogo universiteta.

Sheigal, E. I. (2002). Inauguracionnoe obrashhenie kak zhanr politicheskogo diskursa [Inauguration address as political discourse genre]. Zhanry Rechi, 3, 205-214.

Slishkin, G. G. (2004). Lingvokulturnyj koncept kak sistemnoe obrazovanie [Linguocultural concept as system formation]. Vestnik VGU, Lingvistika $i$ Mezhkulturnaja Kommunikacija, 1, 29-34.

Vicente Mateu, J. A. (1994). La deíxis: Egocentrismo y subjetividad en el lenguaje [The deíxis: Selfcenteredness and subjectivity in the language]. Murcia, Spain: Secretariado de Publicaciones, Universidad.

Vorkachev, S. G. (2004). Schast'e kak lingvokul'turnyj koncept [Happiness as linguocultural concept]. Moscow, Russia: Gnosis.

Wilson, W. (1913). Inaugural address. Retrieved from http://www.speaking-tips.com/Inaugural/WilsonInaugural-1913.aspx

Wilson, W. (1917). Inaugural address. Retrieved from http://www.speaking-tips.com/Inaugural/WilsonInaugural-1917.aspx

Winston, K. (2012, July 26). Poll: Most Americans would vote atheist for president. USA Today. Retrieved from http://usatoday30.usatoday.com/ news/religion/story/2012-07-26/athiest-pollpresident $/ 56516466 / 1$

Yule, G. (2011). Pragmatics. Oxford, UK: Oxford University Press. 